\title{
PAYMENT INSTRUMENTS AS PERCEIVED BY CONSUMERS - RESULTS FROM A HOUSEHOLD SURVEY*
}

BY

\author{
NICOLE JONKER**
}

\begin{abstract}
Summary
Survey results show that Dutch consumers perceive paying in cash as an inexpensive way to pay, compared to paying with electronic payment cards. This finding partly explains the low usage of electronic payment cards in point-of-sale (POS) payments. The objective of the survey was to identify price and non-price features of payment instruments that can be used to stimulate the use of electronic payment cards. Their attractiveness can be increased, through technological modifications that enhance their convenience and by increasing the number of acceptance points. Making it less expensive for consumers to pay with payment cards could also increase the usage of payment cards.
\end{abstract}

Key words: cost efficiency, household survey, non-price features, payment instruments, retail payments

JEL Code(s): D12, D61, G20

\section{INTRODUCTION}

Safe and efficient payment systems are a major precondition for financial stability and economic prosperity in a country. One of the Dutch central bank's (de Nederlandsche Bank or DNB) main tasks is therefore to ensure a safe, reliable, and efficient payment system which is trusted by consumers and businesses. A well functioning payment system facilitates the exchange of goods, services and assets and is the foundation of today's real economy. However, the costs of such payment systems are substantial. Estimates of

* I would like to thank Rein Kieviet, Maarten van Rooij, Stijn Schmitz, Ariena van Wageningen and especially Corrie Vis of CentERdata for their help in collecting the data. Furthermore, I would like to thank two anonymous referees, Wilko Bolt, Hans Brits, Jeff Dominitz, Beth Kiser, Beth Klee, Jed Kolko, Philip Maier, Carlo Winder and participants of the DNB lunch seminar, the FRB research seminar and the Boston FED 'Consumer behaviour and Payment Choice' conference for their valuable comments on earlier versions of this paper. All remaining errors are my own. The views expressed in this paper are mine and do not necessarily reflect those of the Nederlandsche Bank.

** De Nederlandsche Bank, Payments Policy Division, P.O. Box 98, Amsterdam 1000 AB, The Netherlands, e-mail: n.jonker@dnb.nl 
these costs lie around 1-3\% of GDP, see e.g., Humphrey et al. (1996) for the US and Humphrey et al. (2001) for Norway. Brits and Winder (2005) estimated the social costs of point-of-sale (POS) payments in the Netherlands at EUR 2.9 billion, i.e., $0.65 \%$ GDP in 2002.

The costs of retail payments vary with the transaction amount and by payment instrument. Brits and Winder's (2005) study revealed that these costs could be reduced if Dutch consumers were to use the e-purse more often or pay by debit card instead of in cash in case of transaction amounts above around EUR 12. The bulk of all retail payments in the Netherlands are still made in cash (7 billion POS payments in 2002), although debit cards (about 1.25 billion POS payments in 2004) are frequently used in some POS situations. Paying by e-purse (127 million payments in 2004) and credit card (49 million payments in 2004) is not very common in the Netherlands.

What is it that determines nowadays the choice of payment instrument and how may it be steered towards cost-efficient payment instruments? In order to solve this question, DNB, in co-operation with CentERdata, conducted a Public Perception Survey on POS payment instruments among 2000 Dutch households in 2004. The results of the study are presented and discussed in this paper. An important contribution of the present study to the existing literature on payment behaviour is that we asked the respondents to indicate the reasons underlying their payment behaviour in different situations. We asked them to point out the advantages and disadvantages of paying in cash, by debit card, e-purse and credit card in specific POS situations. We did not only take into account reasons reflecting transaction costs or opportunity costs of payment instruments, but we also paid much attention to the appreciation of non-price features of payment instruments like acceptance by retailers, convenience, transaction speed and safety. Such factors also turn out to be important drivers behind the payment choices people make in daily life. The advantage of survey research is that we could easily capture all kinds (economic, psychological, practical, etc) of factors influencing the payment choice and see which factors are most often cited by consumers. We have chosen not to provide a theoretical economic framework on payment choice and use our study on testing it. Such an approach is very useful if one wants to focus on a few specific factors influencing payment behaviour and derive their impact on payment choice analytically. However, such an approach would have limited our analysis to only a small subset of economic factors influencing payment choice, whereas the goal of this study is to gain insight in the big picture. We want to shed light on all the barriers people experience when paying by debit card or e-purse and we want to know who experiences them most. Furthermore, we want to know more about the relative importance of many different economic and non-economic factors influencing payment choice. These insights can be very helpful for 
economists when trying to understand choice behaviour of consumers and for policy makers when trying to remove or mitigate any barriers. This is not only of importance when stimulating consumers to pay in a more costeffective manner with the existing payment instruments, but also with future ones.

From the years 1970s onwards several surveys have been published on payment choice. The Dutch economists Boeschoten, Cramer, Fase and Van Nieuwkerk are pioneers in this field and have published many interesting studies on the demand for money and on payment choice by Dutch consumers, covering the 1970s, 1980s and the 1990s. During the past 10 years, the academic interest in payment studies has grown considerably. The most recent interesting empirical studies include Bolt et al. (2005), Borzekowski and Kiser (2006), Borzekowski et al. (2006), HBD (2002), Van Hove et al. (2005), Hyytinen and Takalo (2004), Klee (2004), Stavins (2001), Schuh and Stavins (2006) and Zinman (2005). The picture emerging from these studies with regard to payment choice and personal characteristics are in line with our results for Dutch consumers.

The structure of this article is as follows. Section 2 provides a brief overview of the theoretical and empirical literature on payment behaviour of consumers. Section 3 summarises the main conclusions of Brits and Winder (2005) regarding the costs of Dutch retail payments and provides some facts about the Dutch retail system. Section 4 discusses the set-up of the Perception Survey and presents the data. Section 5 focuses on payment behaviour of consumers. It deals with the use of payment instruments in different POS situations, particularly the reasons why consumers use a particular instrument in a specific POS situation. Attention is also paid to personal characteristics that influence the use of payment instruments. Section 6 examines the survey results regarding the appreciation of the four instruments in terms of safety, speed, ease of use and cost by the consumers, discusses which consumers are dissatisfied and highlights their aversions. Finally, section 7 summarises and concludes.

\section{LITERATURE PAYMENT BEHAVIOUR}

The payment behaviour of the Dutch has changed considerably during the 20 th century and the first years of the 21 st century due to the introduction of new payment instruments. From the beginning of the 20th century, many theoretical and empirical studies have appeared on cash usage, payment behaviour and payment choice of consumers. Recent theoretical studies focus on the two demand sides in the payment market. This section briefly reviews the theoretical micro-economic and empirical articles that are related to the topic of this study, namely payment behaviour of consumers. 


\subsection{Transaction Demand}

Keynes distinguished in his liquidity preference theory (see e.g., Boeschoten 1992; Mishkin 2000, for a description of Keynes' model) three motives for holding money, namely the transaction motive, the precautionary motive and the speculative motive. The first motive refers to money needed to pay regularly, known payments and the second motive to irregular unplanned payments. Both depend positively on income. The third motive is that people hold money or bonds as a store of value. The speculative demand for money is negatively related to the interest rate. Baumol (1952) and Tobin (1956) developed transaction demand models that show that the transaction demand of households is also negatively related to the interest rate. They introduced the idea that there are opportunity costs involved with holding currency for transactions, which depend positively on the interest rate. Households want to hold less money when the opportunity costs of holding it are high. In later years the Baumol-Tobin framework was refined by many economists, like Buiter and Armstrong (1978), Dotsey (1988) and Kohli (1988). Recent studies on this topic include Duca and Whitesell (1995), Santomero and Seater (1996) and Shy and Tarkka (2002). The outcome of the latter study is very interesting, since it focuses on the usage of cash, the e-purse and the debit card: the three mostly used POS payment instruments in the Netherlands. The authors present a theoretical choice model in which fee structures for both consumers and merchants imposed by card issuers determine the equilibrium transaction domains of the three payment instruments. They find that in equilibrium, e-purses are used for small transactions, cash for intermediate transactions and the debit card for large transactions. However, cash is still overused in this model, being the legal tender.

At the end of the 1990s the focus in payment economics switched to twosided markets. The market for payment instruments is characterised by having two demand sides, consumers and merchants. A payment instrument can only be used if both the consumer and the merchant accept it (see Bolt 2006, for a clear introduction into pricing of electronic payment services with an emphasis on the Dutch case). Network externalities determine to a great extent the value for both groups of end users of being connected to the market of a particular payment instrument and the transaction prices they have to pay. In the Netherlands, banks have set the transaction fee for consumers for all payment instruments (cash and payment cards) at zero, whereas the merchant faces a transaction fee for every card payment made. Bolt and Tieman (2004) show that such a corner solution can arise if consumers are more price elastic than merchants. The owner of the network and the banks use the consumer side of the market to generate a high demand for electronic POS payments, which makes it interesting for the merchant to get connected to the network and accept electronic POS payments, although he has to pay the full price. The 
rapid growth in debit card payments in the Netherlands may be explained by the zero transaction fee for consumers. This way of pricing made paying by debit card for the Dutch actually cheaper than paying by cash because of the opportunity costs of holding money.

\subsection{Empirical Studies}

The first empirical studies examining the demand for money in the Netherlands were published in the 1970s. The academic interest in choice behaviour of consumers between cash and (electronic) payment instruments has been growing fast during the last decades. This development is partly driven by the increasing awareness that the costs involved in using electronic payment instruments for POS payments are often relatively low compared to the costs of paying with paper payment instruments like checks (see e.g., Humphrey and Berger 1990) or cash (see Brits and Winder 2005).

Fase and Van Nieuwkerk (1977) estimated the first currency demand functions for the Netherlands. The banknote circulation in the Netherlands measured as percentage of GDP declined steadily from $11.2 \%$ in 1955 to $10.4 \%$ in 1965, dropped to $8.1 \%$ in 1970 and amounted $6.6 \%$ in 1975 . They modelled the demand for transaction banknotes and hoarding banknotes separately and showed that the income elasticity of the demand for banknotes increases with the size of the denomination. They also showed that the income elasticity for low value banknotes decreased after the introduction of guaranteed checks in 1967, indicating that new payment instruments can substitute traditional payment instruments. Boeschoten (1992) provided an estimation of currency demand in the Netherlands for the period 1956-1990, also including the effect of financial innovations. He also found that the introduction of guaranteed checks led to substantial decline in the demand for banknotes and he found a similar effect on currency demand for the introduction of debitable accounts.

In the 1980s Dutch consumers usually used cash and checks to pay in stores. At the end of the 1980s the debit card was introduced in the Netherlands. Consumers could use it to withdraw cash from ATMs and to pay with it in POS situations. Fase and Boeschoten (1985) and Boeschoten and Fase (1989) used a household study on expenditures to relate the choice of payment instrument with the personal characteristics of consumers and the transaction amount. They found that the use of checks increased with the transaction amount, the age of the consumer and the income of the consumer. Similar results were found by Mot et al. (1989) also using survey data. During the first years of the Dutch debit card it mainly replaced check payments. Boeschoten (1995) reported the results of a yearly household survey on payment behaviour and cash management which were held between 1990 and 1994. In these surveys there were questions on the usage of payment cards 
and also a few about the respondents' opinion about the debit card regarding future usage, convenience, cost and safety. The survey results show that in 1993-1994 the first clear signs that the debit card started to act as a substitute for cash were visible. This substitution process started at gas stations in the beginning of the 1990s, followed a few years later by other points of sale where the transaction amounts can be high, like in supermarkets, department stores and clothes stores. Other interesting results are that about 3/4 of the respondents agreed with the statement that payments cards are safer and more reliable than cash and that between 1990 and 1994 respondents became more positive about the convenience of paying with the debit card. Recent Dutch studies on this topic include HBD (2002), GfK/Interpay (2004) and DNB (2006). They show that the substitution process of cash by the debit card is still running and that in shops where the transaction amounts are high most consumers now usually pay by debit card. Other interesting empirical studies include Borzekowski and Kiser (2006), Borzekowski et al. (2006), Van Hove et al. (2005), Hyytinen and Takalo (2004), Klee (2004), Stavins (2001) Schuh and Stavins (2006), and Zinman (2005). The picture emerging from these studies is that the use of electronic payment cards (debit and e-purse) is negatively related with age and positively related with the educational level of consumers. Furthermore, women seem to use a broader range of payment instruments than men. HBD and Van Hove et al. also consider consumers' opinions on cash the debit card and the e-purse. Cash is regarded as a universally accepted, but relatively unsafe means of payment, whereas the debit card is considered to be modern, easy to use and practical. The finding regarding safety is supported by objective cash usage statistics in the cross-country study by Humphrey et al. (1996): cash usage turns out to be negatively related to the violent crime rate. Finally, empirical evidence for the existence of demand related network effects for electronic card payments was found by Boeschoten (1998) and Stavins (2001).

\section{BACKGROUND}

The survey was carried out in co-operation with the Working Group on Social Efficiency of the National Forum on the Payment System (Maatschappelijk Overleg Betalingsverkeer / 'the Forum'). ${ }^{1}$ The survey is a follow-up to the Cost Survey held in 2003-2004, also by the Nederlandsche Bank, in co-operation with parties represented in the Forum, on the costs involved in point-of-sale (POS) payments (Brits and Winder 2005).

1 This broadly based forum serves as a meeting place for representatives of providers and users of the payment system. These include umbrella organisations of merchants and banks and consumer interest representatives. DNB chairs the Forum and performs its secretarial functions. 


\subsection{Practice and Consequences of Tariff Structure of Dutch POS Payment Services}

Bolt (2006) gives a thorough description of the tariff structure of Dutch retail payment services. Roughly speaking, he distinguishes between direct costs for consumers and merchants, which are directly related to the actual use of payment services, and indirect costs (foregone interest revenues). The direct costs are subdivided in visible costs (fees per transaction, dependent or not on the transaction amount and fixed fees per period, independent of actual use) and invisible costs (value-dating, float). In the Netherlands, consumers and merchants face different tariff structures for using payment instruments. On the one hand, the tariff structure for merchants is directly linked to the use of payment instruments through a differentiated system of payment packages, explicit fees and charges. On the other hand, Dutch consumers are hardly confronted with the costs associated with their payment behaviour. For them, the use of payment instruments seems to be 'free'. Banks only charge them a fixed periodical fee for their debit and credit cards. However, consumers partly cover the costs of retail payments via indirect and hidden direct costs, but also via cross-subsidisation by other banking services. Furthermore, some merchants charge consumers a transaction fee (EUR 0.10 to EUR 0.25) when they pay low transaction amounts by debit card, but most costs are discounted in sales prices.

This practice has adverse economic consequences. Consumers are not stimulated to pay in a cost-effective way and they are unaware of the social costs associated with their payment behaviour. The current way of financing the retail payment system leads to an inefficient use of payment instruments by consumers, which unnecessarily increases the social costs of the retail payment system, causing a misallocation of resources. Cross-subsidisation of the retail payment system by surcharging other banking services also distorts the equilibrium demand for these services. Humphrey et al. (2001), Borzekowski et al. (2006) and Bolt et al. (2005) show that consumers are sensitive to explicit pricing of payment services and that this can indeed stimulate consumers to pay more often electronically, reducing the social costs of the retail payment system.

\subsection{Overview Social Costs Dutch POS Payment System}

The Cost Survey (Brits and Winder 2005) provides an overview of the social costs of retail payments made by the banking sector, the merchants' sector and the central bank. Data on costs are collected using the expertise of the aforementioned sectors and refer to the costs of both cash payments and electronic card payments (debit card, e-purse and credit card). These costs include the costs for the production of the payment 
instruments, construction and maintenance of the infrastructure and processing costs. In 2002, the social costs of cash and electronic card payments in the Netherlands turned out to amount about EUR 2.9 billion, i.e., $0.65 \%$ of GDP or approximately EUR 400 per household. These figures suggest that the Dutch retail payment system is relatively cost-efficient compared to other countries: previous research by Humphrey et al. (1996) presented estimates for the social cost of a country's payment system of around $1-3 \%$ of $\mathrm{GDP}^{2}$ whereas $\mathrm{KBC}$ estimated the social costs of cash alone for Belgium in 1995 at EUR 1 billion, or 0.6\% of GDP (Van Hove 2000).

However, the Cost Survey shows that there is still room for efficiency gains by substituting e-purse payments or debit card payments for cash payments, when transactions exceed a certain threshold. The Cost Survey distinguished between fixed ${ }^{3}$ and variable costs per additional transaction and per extra euro sales. By doing so, payment instrument specific cost functions were retrieved (see Chart $1^{4}$ ), showing the costs for making an additional payment with a particular payment instrument. The variable costs depend on the costs involved with one extra payment transaction (the intersection of the cost function with the y-axis), like data-communication costs made for the authorization of a card payment, and on the costs related to the transaction amount (the slope of the cost function), like counting banknotes and coins or safety related costs. The cost functions were used to determine which payment instrument is most cost-efficient for which transaction amount. The cost differentials involved in the use of each of the four payment instruments are considerable. E-purse payments are the cheapest and credit card payments (not shown in the chart, variable costs of a credit card payment were estimated at EUR 1.09) the most expensive in terms of social costs. A debit card payment costs about EUR 0.19 and is cheaper than a cash payment if the amount paid is around EUR 12 or higher. More e-purse payments and an increased use of the debit card for transaction amounts above EUR 12 instead of cash will reduce the social costs of retail payments. However, how does one change consumers' payment behaviour? In this article we try to shed

2 These costs also include the costs of remote payments. These costs are not included in the Cost survey which focused on POS payments.

3 The fixed costs are related to costs that are not affected by carrying out a specific transaction or by the sales amounts thus generated, like investments in the payment infrastructure. 4 Note that the cost structure and relative costs of using the four payments instruments is probably not the same for all parties in the payment chain, and can even differ between businesses within the same part of the chain (e.g., merchants). The break-even point between cash and debit card differs between parties and businesses and, consequently, these parties or businesses favour different payment instruments and encourage their customers to pay in accordance with their own preferences (see Table 3, p.11 and Table 7, p. 19). However, the conduct of merchants regarding POS payments is beyond the scope of this study. 


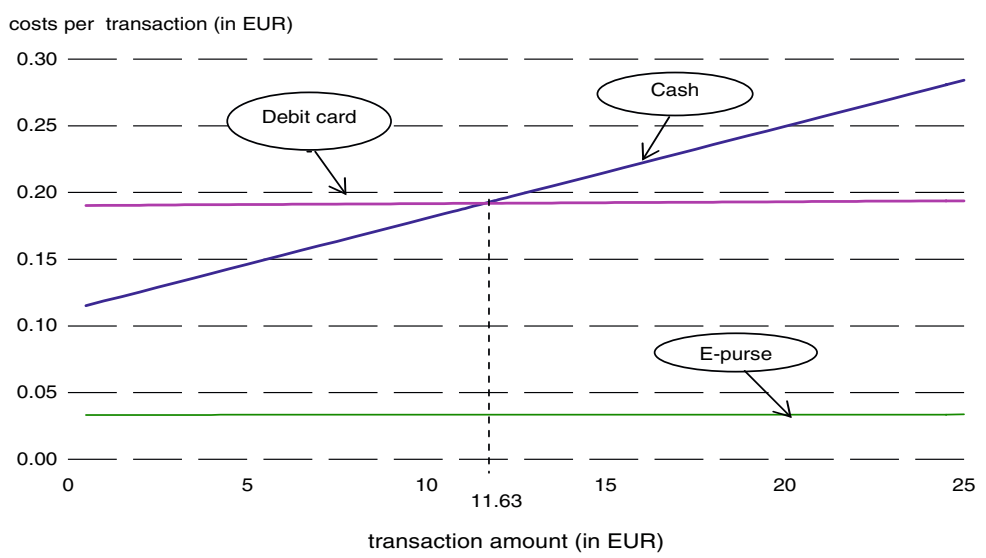

Chart 1 - Variable costs of an additional transaction by cash, debit card and e-purse

Source: Brits and Winder (2005).

some light on what steers consumers' payment behaviour using the Perception Survey.

\section{DATA}

The questionnaire of the Public Perception Survey on POS Payment instruments is part of the DNB Household Survey (DHS). The DNB Household Survey (formerly known as the CentER Savings Survey) is a panel survey that started in 1993. Data are collected every year from a panel (CentERpanel) of some 2,000 Dutch households, of whom several household members may participate in the panel. The data contain information about employment, pensions, accommodation, mortgages, income, assets, debts, health, economic and psychological concepts, and personal characteristics. The DHS data are unique in the sense that they allow studies of both psychological and economic aspects of financial behaviour.

The CentERpanel is an Internet-based telepanel. Data collection with the CentERpanel goes as follows: every week, the panel members fill in a questionnaire on the Internet from their home. In this way, about fifty questionnaires of up to 30 minutes each are answered by the respondents, each year. Data-collection based on Internet questionnaires may have introduced some positive selection bias towards electronic payment instruments in our results. This makes the results of some analyses in this report not perfectly representative for the entire Dutch population. However, we think that the results at least give a clear and quite accurate indication about what consumers in the Netherlands think about cash, the debit card, the e-purse and the credit card and what kind of barriers they face when 
using payment cards. We also expect the pro-electronic bias in this study is rather small, for two reasons. First, new panel members do not need to have access to the Internet to enrol in the panel: the selection of new panel members is done by phone. Households without an Internetconnected computer are provided with a so-called Net.Box which allows them to answer the questions on their TV screen. This selection procedure enhances the representativeness of the panel for the Dutch population. Second, the usage of Internet is nowadays widespread in the Dutch population, except among the elderly. However, the share of people aged 55 or higher in our sample does not differ substantially from the share in the Dutch population.

\subsection{The Public Perception Survey on POS Payment Instruments}

The questionnaire of the Public Perception Survey on POS payment instruments was distributed to the CentERpanel members aged 15 or above, for completion during the weekend of 17 September 2004. Of the 2,716 panel members qualifying for participation in the present survey, 2,019 respondents answered the questionnaire in full. About $98 \%$ of the respondents has a debit card, $49 \%$ has a credit card and $54 \%$ has an e-purse.

The questionnaire started with some general questions on the possession of different payment instruments. Then the respondents were asked to indicate their appreciation of the four payment instruments cash, debit card, e-purse and credit card on a 1-7 scale with regard to the aspects safety, speed, ease of use and the costs they have to make for using the payment instruments. Respondents who were not satisfied were asked to indicate the reason of discontent. Subsequently, the panel members were asked which of the four payment instruments they usually pay with at different POS, i.e., supermarket, food shops, non-food shops, vending machines, filling stations, public transport, parking meters, and the reason why they usually use that payment instrument. The answers on these questions were used to examine respondents' payment habits, to gain insight into the motives underlying their payment behaviour and to identify which features of payment instruments consumers like.

\subsection{Sample Characteristics}

This section discusses the main characteristics of the respondents. Table 1 shows some descriptive statistics of these characteristics for the sample, as well as for the Dutch population as a whole. Generally, the sample represents the Dutch population fairly well, although there are some differences. We think most results of the perception survey also hold for the Dutch population; however some results should be treated cautiously and may only 
TABLE 1 - DESCRIPTIVE STATISTICS DUTCH POPULATION AND RESPONDENTS OF THE SURVEY

\begin{tabular}{llc}
\hline Variable & Population (\%) & Survey (\%) \\
\hline Male & 49.5 & 53.2 \\
Partner=1 & 59.1 & 79.5 \\
Age 15-24 years & 14.6 & 8.3 \\
$\quad$ 25-34 years & 17.7 & 15.7 \\
35-44 years & 19.8 & 19.7 \\
45-54 years & 17.4 & 23.0 \\
55-64 years & 13.8 & 16.7 \\
65 years and older & 16.8 & 16.6 \\
Education = primary education & 12.5 & 7.6 \\
Lower vocational/general secondary education & 24.8 & 26.5 \\
Interm. vocational or general education & 31.3 & 31.9 \\
Higher vocational education & 16.1 & 23.7 \\
University & 7.4 & 10.3 \\
Lives in a major city & 19.0 & 14.1 \\
City & 22.4 & 25.7 \\
Town & 17.7 & 21.4 \\
Village & 19.6 & 23.4 \\
Countryside & 20.8 & 15.5 \\
\hline
\end{tabular}

give an indication about the beliefs of Dutch consumers regarding certain payment instruments. In the discrete choice regression analyses in section 5 and 6 , the characteristics were used as explanatory variables to identify the factors influencing payment behaviour of individuals.

There are 2,019 respondents of whom 53\% are male and $47 \%$ are female. The average age of the respondents is 47 years, which is somewhat higher than the average age of the Dutch population (older than 15 years). Almost $80 \%$ of the respondents have a partner (married or living together), whereas this holds for $60 \%$ of the Dutch population. ${ }^{5}$ The educational level of the respondents seems to be slightly higher than for the whole population. The sample has relatively few respondents with at most lower vocational education and has relatively many respondents graduated at higher vocational education or university. This may have biased some survey results. We will pay attention to this in the discussion of the results and indicate the direction

5 Marital status hardly influences payment behaviour and people's appreciation of payment instruments (see regression results discussed in sections 5 and 6). Consequently, the difference between the share of married people in the sample and in the Dutch population in marital will not cause any biases in the results. 
of the bias. ${ }^{6}$ This is possible since there are enough respondents within each educational level in the sample to draw conclusions per educational level. The survey results show that the educational biases are small. Finally, the distribution of the respondents over the five urbanisation categories differs somewhat from the Dutch population: relatively many respondents live in smaller cities or towns and relatively few in the countryside or in one of the major cities. We do not exactly know what causes these differences. They may be due to differences between the composition of the panel and the Dutch population or they may stem from differences in response rates between different urbanisation categories. However, the Survey results indicate that biases due to differences in urbanisation are small as well.

\section{PAYMENT BEHAVIOUR}

\subsection{Which Instruments do Consumers Use to Pay at Different POS} Situations?

Respondents were asked in 2004 which payment instrument they tend to use in eight different POS situations, together forming a representative sample of points-of-sale in the Netherlands. Table 2 and Chart 2 present the results. Table 2 focuses on the number (ranging between 0 and 8 ) out of the eight different POS situations at which consumers usually pay with one particular payment instrument. The table provides insight into the intensity with which

TABLE 2 - PERCENTAGES OF CONSUMERS WHO TEND TO PAY WITH

A PARTICULAR PAYMENT INSTRUMENT AT (0-8) DIFFERENT

POS LOCATIONS, 2004

\begin{tabular}{lrrrr}
\hline $\begin{array}{l}\text { (Column percentages) } \\
\text { Number of POS }(\max =8)\end{array}$ & Cash & Debit card & E-purse & Credit card \\
\hline None & & & & \\
1 & 6 & 8 & 68 & 84 \\
2 & 12 & 11 & 24 & 12 \\
3 & 21 & 19 & 6 & 3 \\
4 & 22 & 28 & 1 & 1 \\
5 & 19 & 22 & 0 & 0 \\
6 & 11 & 9 & 0 & 0 \\
7 & 5 & 2 & 0 & 0 \\
8 & 2 & 0 & 0 & 0 \\
Total & 2 & 0 & 0 & 0 \\
\hline
\end{tabular}

6 The results indicate that differences in perceptions between differently educated respondents are sometimes statistically significant, but the magnitude of these differences is rather small. 


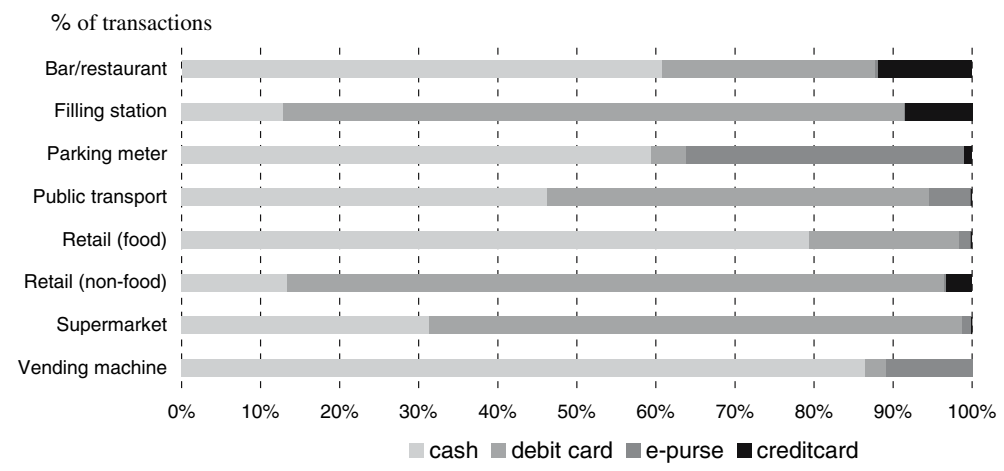

Chart 2 - Payment behaviour by payment instrument and by POS situation, 2004

consumers make use of the payment instruments. For instance, the second column in this table indicates that for $6 \%$ of the respondents cash is in none of the eight POS situations the most commonly used payment instrument, $12 \%$ of the respondents tend to use cash in one of the eight POS situations, $21 \%$ of the respondents mostly use cash in two of the eight POS situations, etc. Chart 1 shows, for each of the eight POS situations separately, the frequency distribution of the four commonly used payment instruments. For example, the first bar in Chart 1 corresponds with the POS situation 'bars and restaurants', where about $60 \%$ of the respondents usually pay in cash, about $28 \%$ mostly pay by debit card, and $12 \%$ mostly by credit card.

Both Table 2 and Chart 2 indicate that consumers use cash and the debit card most often, while they make fewer payments by e-purse or credit card. According to Table 2, only $6 \%(8 \%)$ of the consumers did not indicate cash (debit card) as the most used payment instrument at any of the eight POS situations. On the other hand, 2/3 of the consumers do not or rarely use the e-purse and $84 \%$ rarely pay by credit card: these figures show that the Netherlands is not a credit card country, like the US but more a cash and debit card country like e.g., Scandinavian countries. Consumers who use the e-purse or credit card usually do this only at 1 or 2 different points-of-sale, while cash and the debit card are mostly used at, on average, 3 different POS situations.

From a social cost perspective (see section 3.2), it is positive that consumers having to decide between paying cash or by debit card usually pay with cash in situations where the average purchase amounts are low, as in vending machines and in smaller shops (food), whereas they are more likely to use the debit card at points of sale where checkout amounts tend to be higher, as in supermarkets, filling stations and (non-food) shops. This indicates that many consumers already pay rather cost efficiently. The low-level use of e-purses 
indicates that consumers could improve the cost-efficiency of their payment behaviour.

\subsection{Reasons Given for Choosing an Instrument}

Respondents were asked to explain their favourite choice of payment instrument in particular POS situations. Their answers are summarised in Table 3. The picture that emerges varies somewhat between payment instruments, but very little between POS situations. Remarkably, irrespective of either the payment instrument or the type of location, the most-cited reason for choosing a particular instrument was the perceived speed of the payment process. The only payment instrument where transaction speed played no significant role was the credit card. The Cost Survey revealed the following average transaction times: cash, 19 seconds; debit card, 26 seconds; e-purse, 14 seconds; and credit card, 28 seconds. In a public campaign to encourage the use of the e-purse or possible future prepaid card-based payment instruments, consumer information could stress the high transaction speed of e-purse payments. Furthermore, introducing a new, contactless electronic purse solution will further increase the transaction speed and can enhance the e-purse's attractiveness as a payment instrument.

A reason cited by many consumers who pay mostly in cash is that it helps them monitor their expenses: they can see their purses emptying. This might be a major reason why some groups of consumers prefer cash to electronic payment cards (see section 5.3). Another often-cited motive for using cash is that in some POS situations (e.g., vending machines or small shops) only cash is accepted. Small merchants often do not have payment terminals in order to save on investment costs and subscription and transaction fees on the possession and use of the electronic payment infrastructure. This illustrates a special feature of the market for payments: it is a two-sided market in which both consumers and merchants are needed in order to make electronic payments possible. It indicates that the focus should not only be on consumer demand, but also on the supply side, especially by paying attention to the merchants whom only accept cash. One feature distinguishing cash from the debit card and the credit card, is that it can be used anonymously. However, this feature does not seem to be the driving force behind the use of cash by Dutch consumers: depending on the payment situation, only $1-2 \%$ of the respondents state that they pay in cash because of anonymity reasons. This reason was mentioned most often for the hotel and catering industry. This finding is supported by the study of Van Hove et al. (2005) among Belgian consumers. Very interesting from an economic point of view is that $8 \%{ }^{7}$ of

7 In reality this percentage may be even higher, since our sample is relatively wealthy compared to the Dutch population and may be less sensitive for costs. 
TABLE 3 - MOST-CITED TWO REASONS FOR CHOOSING MOST-USED PAYMENT INSTRUMENT BY POS TYPE

\begin{tabular}{|c|c|c|c|c|c|c|c|c|}
\hline$\%$ Responses & Cash & & Debit card & & E-purse & & Credit card & \\
\hline \multirow[t]{2}{*}{ Bar/Restaurant } & Fastest & 42 & Short of cash & 41 & \multirow[t]{2}{*}{ - } & & Short of cash & 27 \\
\hline & $\begin{array}{l}\text { Expense } \\
\text { monitoring }\end{array}$ & 16 & Fastest & 36 & & & $\begin{array}{l}\text { Delayed } \\
\text { payment }\end{array}$ & 21 \\
\hline \multirow[t]{2}{*}{ Public transport } & Fastest & 61 & Fastest & 48 & Fastest & 42 & \multirow[t]{2}{*}{-} & \\
\hline & $\begin{array}{l}\text { Expense } \\
\text { monitoring }\end{array}$ & 14 & Exact payment & 37 & $\begin{array}{l}\text { No searching } \\
\text { for coins }\end{array}$ & 21 & & \\
\hline \multirow[t]{2}{*}{ Parking meter } & Fastest & 52 & Fastest & 42 & $\begin{array}{l}\text { No searching } \\
\text { for coins }\end{array}$ & 32 & \multirow[t]{2}{*}{-} & \\
\hline & $\begin{array}{l}\text { Only possibil- } \\
\text { ity }\end{array}$ & 26 & Exact payment & 37 & $\begin{array}{l}\text { Cash not } \\
\text { accepted }\end{array}$ & 23 & & \\
\hline \multirow[t]{2}{*}{ Vending machine } & Fastest & 44 & Fastest & 67 & $\begin{array}{l}\text { No searching } \\
\text { for coins }\end{array}$ & 27 & \multirow[t]{2}{*}{-} & \\
\hline & $\begin{array}{l}\text { Only possibil- } \\
\text { ity }\end{array}$ & 26 & & & Fastest & 27 & & \\
\hline \multirow[t]{2}{*}{ Supermarket } & Fastest & 45 & Fastest & 44 & \multirow[t]{2}{*}{ Fastest } & 91 & \multirow[t]{2}{*}{ - } & \\
\hline & $\begin{array}{l}\text { Expense } \\
\text { monitoring }\end{array}$ & 36 & Short of cash & 21 & & & & \\
\hline \multirow[t]{2}{*}{ Filling station } & Fastest & 49 & Fastest & 39 & \multirow[t]{2}{*}{ - } & & $\begin{array}{l}\text { Delayed } \\
\text { payment }\end{array}$ & 26 \\
\hline & $\begin{array}{l}\text { Expense } \\
\text { monitoring }\end{array}$ & 25 & Short of cash & 27 & & & $\begin{array}{l}\text { Expense } \\
\text { monitoring }\end{array}$ & 16 \\
\hline \multirow[t]{2}{*}{ Shops (food) } & Fastest & 41 & Fastest & 50 & \multirow[t]{2}{*}{ Fastest } & 69 & \multirow[t]{2}{*}{-} & \\
\hline & $\begin{array}{l}\text { Only possibil- } \\
\text { ity }\end{array}$ & 20 & Short of cash & 22 & & & & \\
\hline \multirow[t]{2}{*}{ Shops (non-food) } & Fastest & 50 & Short of cash & 33 & \multirow[t]{2}{*}{ - } & & $\begin{array}{l}\text { Delayed } \\
\text { payment }\end{array}$ & 36 \\
\hline & $\begin{array}{l}\text { Expense } \\
\text { monitoring }\end{array}$ & 33 & Fastest & 42 & & & Short of cash & 28 \\
\hline
\end{tabular}

Explanation: Reasons given were cited by at least 10 panel members.

Percentages represent respondents citing the reason given as a share of total respondents who usually pay with a particular payment instrument in a particular location.

the consumers pay in cash at food shops in order to avoid additional fees for paying by debit card. This suggests that pricing the use of payment instruments may steer Dutch consumers towards cost effective payment behaviour, i.e., the price elasticity for the demand of payment instruments is positive. This was also found by Humphrey et al. (2001) for Norway. Another $8 \%$ of 
Dutch consumers state that they pay in cash because of the low transaction amounts at these shops. If one only considers the choice between cash and debit card (e-purse is still a niche instrument), these $8 \%$ of consumers pay in a cost-effective manner.

The most important reasons given for using the debit card, apart from transaction speed, are lack of sufficient cash (bars, restaurants and shops) and the wish to pay exact amounts (parking meters and ticket machines for public transport. Active e-purse users use their card to avoid searching for coins. Some parking meters do not even accept cash and force the customer to pay by e-purse. Few panel members indicated that they usually paid by credit card at particular POS locations. Those who did, used their card mostly in bars and restaurants, filling stations and nonfood shops. Most-cited reasons to pay by credit card were lack of sufficient cash and the wish to postpone actual payment until a later date. The 'lack-of-sufficient-cash' argument can be interpreted as consumers face relatively low transaction costs for cash payments compared to card payments. They do not have to go to the bank or the ATM to withdraw extra money to pay for their expenses. Postponing the actual payments lowers the opportunity costs of paying. It offers households an opportunity to bridge temporary overdrafts in their bank accounts without having to borrow money from the bank or to pay interest on the overdraft.

\subsection{Who are Active Debit and E-purse Users and Who Are Not? Probit Results}

The DNB Household Survey, of which the present Perception Survey is a part, collects many data on personal characteristics from panel members. This information has been used to identify which personal characteristics influence people's choice of payment instrument, using probit regression analysis (see e.g., Greene 1993 for a discussion of binary choice models). The results, together with the perceived pros and cons of the payment instruments (see section 6), can be helpful in understanding consumers' payment preferences and can be used to improve the effectiveness of measures to encourage cost efficient payment behaviour.

We have distinguished four groups of payers: (1) cash payers, (2) frequent debit card users, (3) frequent e-purse users and (4) frequent credit card users. Classification of panel members to these groups is based on the frequency distribution in Table 2. The thresholds for belonging to a payers group or not were chosen in such a way that belonging to the group is not 'forced' (think of POS situations with only one accepted payment instrument) and is neither extremely rare (high threshold) nor very ordinary (low 
threshold). ${ }^{8}$ Cash payers are respondents who pay at most at one POS situation electronically, frequent debit card users pay at least at three different POS locations usually by debit card and frequent e-purse users pay at least at two different POS locations usually by e-purse. Frequent credit card users are people who usually pay by credit card at least at one POS location. Panel members may belong to more than one group or to none at all. There are panel members who use all four payment instruments, depending on the POS situation. Panel members can belong to more than one group, but never to all. Four probit regressions ${ }^{9}$ were estimated, each focussing on one group of payers. The dependent variable equals one if a respondent belongs to the corresponding type of payers. Table 4 shows both estimated coefficients as well as marginal effects $\mathrm{dF} / \mathrm{dx} .{ }^{10}$ Coefficients that are significantly different from zero have a superscript with one or more *s.

Remarkably, men are relatively frequent cash payers, and relatively intensive e-purse and credit card users as well. Women, by contrast, use their debit card in many different situations. The marginal effects show that men have a $6 \%$ higher probability of being a frequent cash or credit card user than women, a $7 \%$ lower probability of being a frequent debit card user and a 3\% higher probability of being a frequent e-purse user. The differences in payment behaviour between men and women seem to stem from two sources. The first one is that men and women pay differently in the same payment situation. The second source is that they differ in the kind and number of POS locations they visit. Women visit more and different POS locations than men. This can explain why there are relatively many women in the frequent debit card user group and relatively few in the frequent cash user group. On the other hand, men travel relatively more for business (by car), which explains why they use their e-purse (parking) and their credit card (parking, hotel) more often than women. Similar findings regarding gender have also been found by others, like Mot et al. (1989) and Stavins (2001).

Age influences the decision on whether to use cash, the e-purse or the credit card. People in the youngest age group pay relatively often in cash,

8 We have also estimated probit models using a slightly different group definition, e.g., frequent debit card payers are people who pay at least at four different POS locations by debit card or cash payers are consumers who mainly pay with cash at every POS location. Using a somewhat different definition for the dependent variables hardly altered the estimation results indicating that the results are quite robust with respect to the classification of respondents in groups.

9 Poisson count models have also been estimated with the number of POS situations where one usually pays with a particular payment instrument as a dependent variable. Most estimation results are similar to the presented probit results. This shows that the reported results are quite robust.

10 For a discrete change in case of a dummy variable $\mathrm{x}, \mathrm{dF} / \mathrm{dx}$ refers to the change from 0 to 1 of $\mathrm{x}$. 
TABLE 4 - PROBIT RESULTS: FREQUENT USERS CASH, DEBIT CARD, E-PURSE AND CREDIT CARD

\begin{tabular}{|c|c|c|c|c|c|c|c|c|}
\hline & \multicolumn{2}{|c|}{ Cash } & \multicolumn{2}{|c|}{ Debit card } & \multicolumn{2}{|c|}{ e-purse } & \multicolumn{2}{|c|}{ Credit card } \\
\hline & Coef. & $\mathrm{dF} / \mathrm{dx}$ & Coef. & $\mathrm{dF} / \mathrm{dx}$ & Coef. & $\mathrm{dF} / \mathrm{dx}$ & Coef. & $\mathrm{dF} / \mathrm{dx}$ \\
\hline Male & $0.278^{* *}$ & $0.063^{* *}$ & $-0.190^{* *}$ & $-0.069^{* *}$ & $0.033^{* *}$ & $0.012^{* *}$ & $0.267^{* *}$ & $0.055^{* *}$ \\
\hline Married & -0.085 & -0.020 & -0.070 & -0.025 & $-0.035^{* *}$ & $0.019^{* *}$ & 0.127 & 0.025 \\
\hline Age $15-24$ & $0.435^{*}$ & $0.118^{*}$ & -0.043 & -0.015 & -0.004 & 0.042 & $-1.993^{* *}$ & $-0.161^{* *}$ \\
\hline Age $25-34$ & $-0.349^{* *}$ & $-0.070^{* *}$ & 0.201 & 0.074 & $0.094^{* *}$ & $0.041^{* *}$ & $-0.262^{*}$ & $-0.049^{*}$ \\
\hline Age $35-44$ & -0.116 & -0.025 & 0.109 & 0.040 & 0.033 & 0.029 & $-0.264^{*}$ & $-0.050^{*}$ \\
\hline Age $45-54$ & -0.066 & -0.015 & 0.019 & 0.007 & 0.022 & 0.026 & $-0.239^{*}$ & $-0.046^{*}$ \\
\hline Age 55-64 & -0.140 & -0.030 & 0.048 & 0.017 & 0.025 & 0.026 & -0.084 & -0.017 \\
\hline City & -0.105 & -0.023 & $0.276^{* *}$ & $0.102^{* *}$ & -0.004 & 0.019 & 0.076 & 0.016 \\
\hline Town & -0.069 & -0.015 & $0.276^{* *}$ & $0.102^{* *}$ & -0.010 & 0.020 & 0.063 & 0.013 \\
\hline Village & -0.111 & -0.024 & $0.214^{*}$ & $0.079^{*}$ & 0.006 & 0.022 & 0.027 & 0.006 \\
\hline Countryside & -0.130 & -0.028 & $0.254^{* *}$ & $0.095^{* *}$ & 0.012 & 0.025 & 0.065 & 0.014 \\
\hline d_employed & $-0.168^{*}$ & $-0.038^{*}$ & -0.035 & -0.013 & -0.006 & 0.016 & 0.133 & 0.027 \\
\hline d_study & 0.114 & 0.027 & $-0.539 * *$ & $-0.169^{* *}$ & 0.066 & 0.065 & 0.261 & 0.061 \\
\hline $\begin{array}{l}\text { Net } \\
\text { monthly hh } \\
\text { Income < } \\
\text { EUR } 1150\end{array}$ & $0.459^{* *}$ & $0.125^{* *}$ & $-0.268^{* *}$ & $-0.091^{* *}$ & $-0.050^{* *}$ & $0.013^{* *}$ & $-0.379^{* *}$ & $-0.065^{* *}$ \\
\hline $\begin{array}{l}\text { EUR } 1150 \leq \\
\text { income < } \\
\text { EUR } 1800\end{array}$ & $0.220^{* *}$ & $0.053^{* *}$ & -0.134 & -0.048 & $-0.026^{*}$ & $0.014^{*}$ & $-0.507^{* *}$ & $-0.089^{* *}$ \\
\hline $\begin{array}{l}\text { EUR } 1800 \leq \\
\text { income < } \\
\text { EUR } 2600\end{array}$ & 0.026 & 0.006 & 0.025 & 0.009 & -0.005 & 0.013 & $-0.298^{* *}$ & $-0.058^{* *}$ \\
\hline $\begin{array}{l}\text { Intermediate } \\
\text { voc. ed. }\end{array}$ & $-0.284^{* *}$ & $-0.059^{* *}$ & $0.192^{* *}$ & $0.071^{* *}$ & 0.023 & 0.020 & -0.085 & -0.017 \\
\hline $\begin{array}{l}\text { General sec. } \\
\text { ed. }\end{array}$ & $-0.271^{* *}$ & $-0.055^{* *}$ & $0.330^{* *}$ & $0.124^{* *}$ & $0.009^{* *}$ & $0.021^{* *}$ & -0.104 & -0.021 \\
\hline $\begin{array}{l}\text { High voc. } \\
\text { ed. }\end{array}$ & $-0.461^{* *}$ & $-0.092^{* *}$ & $0.312^{* *}$ & $0.116^{* *}$ & $0.048^{* *}$ & $0.020^{* *}$ & 0.133 & 0.029 \\
\hline University & $-0.370^{* *}$ & $-0.071^{* *}$ & $0.206^{*}$ & $0.076^{*}$ & $0.052^{* *}$ & $0.029^{* *}$ & 0.082 & 0.018 \\
\hline p_Gro & 0.196 & 0.049 & -0.113 & -0.040 & $-0.054^{* *}$ & $0.014^{* *}$ & $-0.415^{*}$ & $-0.068^{*}$ \\
\hline p_Fri & -0.181 & -0.038 & -0.218 & 0.075 & 0.004 & 0.028 & $-0.427^{* *}$ & $-0.070^{* *}$ \\
\hline p_Dre & 0.048 & 0.011 & 0.143 & 0.053 & 0.003 & 0.032 & $-0.639^{* *}$ & $-0.092^{* *}$ \\
\hline p_Ove & 0.152 & 0.037 & -0.176 & -0.061 & $-0.049^{* *}$ & $0.014^{* *}$ & -0.254 & -0.046 \\
\hline p_Fle & 0.109 & 0.026 & 0.083 & 0.030 & -0.039 & 0.025 & -0.110 & -0.021 \\
\hline p_Gel & -0.040 & -0.009 & 0.021 & 0.008 & -0.002 & 0.020 & -0.163 & -0.031 \\
\hline p_Utr & 0.072 & 0.017 & 0.067 & 0.024 & 0.005 & 0.027 & 0.078 & 0.017 \\
\hline p_Nh & 0.171 & 0.041 & $-0.215^{* *}$ & $-0.075^{* *}$ & -0.014 & 0.016 & $-0.305^{* *}$ & $-0.055^{* *}$ \\
\hline p_Zee & 0.055 & 0.013 & $-0.455^{* *}$ & $-0.145^{* *}$ & 0.043 & 0.040 & -0.328 & -0.056 \\
\hline p_Nbr & 0.189 & 0.046 & $-0.226^{* *}$ & $-0.078^{* *}$ & -0.010 & 0.018 & $-0.221^{*}$ & $-0.042^{*}$ \\
\hline p_Lim & 0.184 & 0.045 & $-0.375^{* *}$ & $-0.124^{* *}$ & -0.014 & 0.021 & 0.164 & 0.037 \\
\hline _cons & $-0.835^{* *}$ & & $-0.521^{* *}$ & & $-1.594^{* *}$ & & $-0.799^{* *}$ & \\
\hline
\end{tabular}


TABLE 4 - CONTINUED

\begin{tabular}{|c|c|c|c|c|c|c|c|c|}
\hline & \multicolumn{2}{|c|}{ Cash } & \multicolumn{2}{|c|}{ Debit card } & \multicolumn{2}{|c|}{ e-purse } & \multicolumn{2}{|c|}{ Credit card } \\
\hline & Coef. & $\mathrm{dF} / \mathrm{dx}$ & Coef. & $\mathrm{dF} / \mathrm{dx}$ & Coef. & $\mathrm{dF} / \mathrm{dx}$ & Coef. & $\mathrm{dF} / \mathrm{dx}$ \\
\hline No. obs & \multicolumn{2}{|c|}{2019} & \multicolumn{2}{|c|}{2019} & \multicolumn{2}{|c|}{2019} & \multicolumn{2}{|c|}{2019} \\
\hline No. pos. obs & \multicolumn{2}{|c|}{332} & \multicolumn{2}{|c|}{674} & \multicolumn{2}{|c|}{159} & \multicolumn{2}{|c|}{323} \\
\hline Pseudo $\mathrm{R}^{2}$ & \multirow{2}{*}{\multicolumn{2}{|c|}{$\begin{array}{c}0.087 \\
-823.72\end{array}$}} & \multirow{2}{*}{\multicolumn{2}{|c|}{$\begin{array}{c}0.043 \\
-1230.31\end{array}$}} & \multirow{2}{*}{\multicolumn{2}{|c|}{$\begin{array}{c}0.061 \\
-522.75\end{array}$}} & \multirow{2}{*}{\multicolumn{2}{|c|}{$\begin{array}{c}0.095 \\
-803.46\end{array}$}} \\
\hline $\begin{array}{l}\text { Log likeli- } \\
\text { hood }\end{array}$ & & & & & & & & \\
\hline
\end{tabular}

$*$ and ${ }^{* *}$ indicate significance at the $90 \%$ and $95 \%$ level of significance, respectively.

even more than the elderly (reference group), whereas people in the 2534 age bracket use relatively little cash and pay relatively often by e-purse, compared to the elderly. Age does not seem to play a role in choosing the debit card to pay. In contrast to e-purses, debit cards have come into general use across all age groups. Usage of the credit card increases with age. As with gender, some of the age differences in payment instrument usage can be explained from the number and kind of POS locations the respondents visit. Young people are often not a head of a household yet and are only responsible for purchases they do for themselves and not for the entire household. Furthermore, they often do not have a driving license yet. This limits the variety of POS locations they visit. As a result, young people are relatively often classified as active cash users. Finally, people aged below 18 years are not entitled to have an own credit card: this partly explains why there are relatively few young people among the active credit card users.

Income and educational levels are also significant factors in the choice of payment methods: the higher a person's income and educational level, the more 'modern' their payment behaviour is. Perhaps there is a connection here to the cited benefit of paying in cash, i.e., that it allows one to keep track of expenses. This benefit may be more important for the lower income categories (net monthly household income below EUR 1800) that usually include people educated to lower and medium levels. The medium (net monthly household income between EUR 1800-2600) and higher income categories (net monthly household income above EUR 2600) tend to go for the ease of paying by debit card (never short of money, no searching for coins, no heavy purse). Furthermore, people with a low or medium household income have a $6-9 \%$ lower probability of being a frequent credit card payer than people with a high household income. 
Degree of urbanisation and regional differences both have a significant impact on payment behaviour. People living in a major city have an $8-11 \%$ lower probability of being a frequent debit card user than people living in towns and villages. Regional differences significantly influence payment behaviour. For example, debit card usage is relatively low in the southern provinces of the Netherlands and in North Holland. Stavins (2001) also found, after controlling for personal characteristics, geographical differences in the use of payment instruments in the US. Network externalities may play a role here, although it is not clear how to test for the existence of network externalities in electronic payments, using the DNB Household panel. Information on the supply side (POS accepting electronic payments) is also necessary.

Generally, the effects presented here are in line with other recently obtained results. The results for the debit card and the e-purse, regarding age, and educational level were also reported by Loix et al. (2005). Klee (2004) also showed that the usage of the debit card increases with income and educational level and Boeschoten (1992) found an income effect for the credit card. Stavins (2001) reported a negative correlation between age and both ATM card usage (cash) and smart card usage, and a positive correlation between credit card usage and age, income and educational level.

\section{APPRECIATION AND AVERSIONS}

Policies to encourage the use of the debit card and e-purses could focus on two groups of people, (1) people who already make regular use of electronic payment methods and (2) people who currently make little or no use of these payment instruments. The first group may be encouraged to increase their usage of electronic payment instruments, whereas the second group may be persuaded to start using such instruments. Knowledge about thresholds (e.g., on the supply side) and aversions (e.g., psychological) can be used to lower or even remove them. This section discusses consumers' appreciation of each of the instruments, it takes a closer look at the characteristics of dissatisfied consumers using a discrete ordered probit model and it highlights the aversions of these dissatisfied consumers.

\subsection{Appreciation}

Respondents indicated their appreciation of the four payment instruments with regard to the aspects safety, speed, cost and ease of use on a 1-7 scale (see Table 5). At this ordinal scale a score of 4 indicates a neutral position. The aspects safety, speed, cost and ease of use were selected because together they largely determine whether and how frequently consumers use a particular means of payment. The safety of an instrument should be read as the 
TABLE 5 - APPRECIATION OF PAYMENT INSTRUMENT BY FACTOR (AVERAGES AND STANDARD DEVIATIONS)

\begin{tabular}{|c|c|c|c|c|c|c|c|c|}
\hline & \multicolumn{2}{|c|}{ Safety ${ }^{\mathrm{a}}$} & \multicolumn{2}{|c|}{ Speed $^{b}$} & \multicolumn{2}{|c|}{$\operatorname{Cost}^{\mathrm{c}}$} & \multicolumn{2}{|c|}{ Ease of use $\mathrm{d}^{\mathrm{d}}$} \\
\hline & avg & sd & avg & sd & avg & sd & avg & sd \\
\hline Cash & 5.0 & (1.4) & 5.5 & (1.4) & 1.8 & $(1.3)$ & 5.7 & (1.4) \\
\hline Debit card & 5.6 & (1.1) & 5.8 & (1.0) & 3.0 & $(1.5)$ & 6.3 & (1.0) \\
\hline E-purse & 5.3 & (1.4) & 5.7 & (1.3) & 2.9 & $(1.5)$ & 5.4 & (1.6) \\
\hline Credit card & 4.8 & $(1.5)$ & 5.1 & (1.4) & 4.3 & (1.6) & 5.4 & (1.5) \\
\hline
\end{tabular}

a) $1=$ very unsafe; $7=$ very safe, b) $1=$ very slow; $7=$ very fast, c) $1=$ very cheap; $7=$ very expensive and d) $1=$ very hard to use; $7=$ very easy to use.

absence of perceived physical danger and financial risk in using the instrument; its speed denotes the time needed to perform a transaction; costs relate to costs for the consumer for the possession and actual use of a payment instrument; and ease of use was defined as the effort needed on the part of the consumer to pay with a particular instrument.

Table 5 shows that the respondents were generally satisfied to very satisfied with the use of the four payment instruments: average appreciation was favourable on all scores. The growing confidence and popularity of payment cards already shown by Boeschoten (1995) has continued. The debit card is perceived as the safest, fastest and most user-friendly payment instrument. Cash is regarded as the cheapest. Comparing the average scores given by low educated respondents with the average scores by the entire sample shows that the magnitude of the differences in average group scores is rather small (the largest differential is 0.18 for the costs of credit card payments), which indicates that the results of this sample are also representative for the Dutch population. The average ratings of the four payment instruments are significantly different from each other, according to the mean comparison tests and several association tests (Pearson $\chi^{2}$ test, or Goodman and Kruskal's $\gamma$ test). Only the average scores of the e-purse and the credit card on convenience do not differ significantly.

Remarkably, of the respondents who found paying with cash expensive, $39 \%$ cite cardholder fees as the reason. Apparently, they associated the debit card mostly with cash withdrawals. Opportunity costs like foregone interest revenues were hardly mentioned. Although the credit card was least appreciated, most respondents still considered it safe, fast and easy to use. The e-purse, while scoring lowest of all on user-friendliness, still received very satisfactory marks. Active e-purse users were considerably more satisfied with its ease of use (average mark 6.0) than non-users (5.0), while they were also more satisfied with the e-purse's transaction speed (average mark 6.1 against 


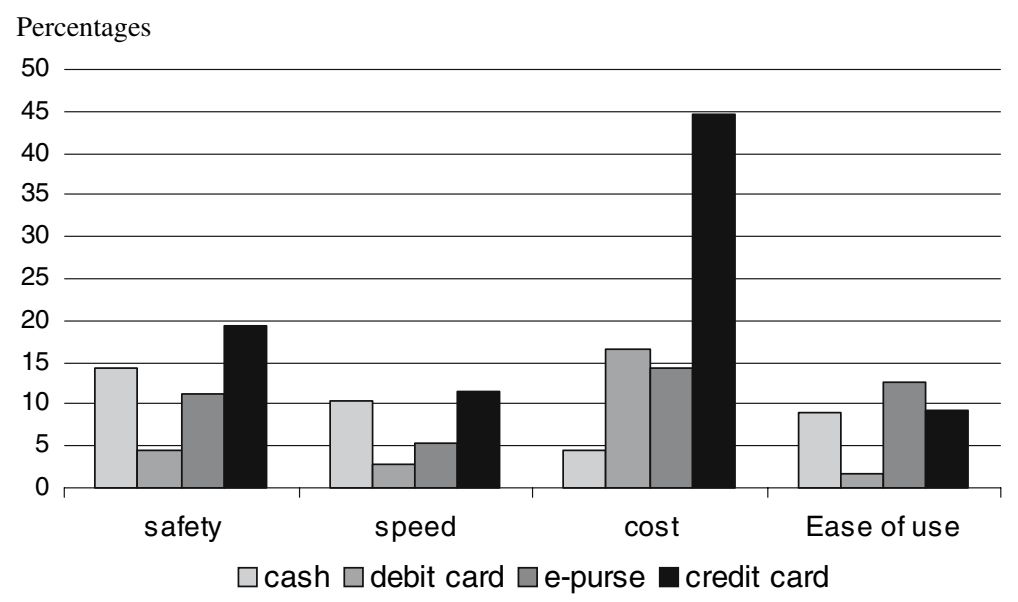

Chart 3 - Dissatisfied consumers by perception factor and payment instrument

5.4 for non-users) and its safety (users: 5.6, on average, against non-users: 4.9). Apparently, consumers' appreciation of the e-purse may increase once they get used to it, although the results may also be explained by selectivity.

In addition to average appreciation, attention is also paid to the share of panel members who gave negative scores. Chart 3 shows these shares by perception factor. The share of dissatisfied respondents varies from 1.6\% (debit card's ease of use) to $44.7 \%$ (credit card's costs), with most shares coming out between $10 \%$ and $15 \%$. Again, the credit card received the largest number of negative scores on three of the four aspects. Only on ease of use does the e-purse receive less appreciation from more respondents $(12.7 \%)$ than the credit card $(9.4 \%)$. And here, too, there is a large difference between active users and non-users: $18 \%$ of non-users perceived the e-purse as being userunfriendly, against only $4 \%$ of users. The debit card and, to a slightly lesser extent, the e-purse were regarded as expensive by a number of respondents $(14-16 \%)$. On the other aspects, the debit card received unfavourable marks from less than $5 \%$ of panel members.

\subsection{Profile of the Dissatisfied: Ordered Probit Results}

The survey results were also used to examine who were dissatisfied with particular features of the four payment instruments considered. The dependent variables are the respondents' ratings which measure the level of satisfaction regarding safety, speed, cost and ease of use for each of the four payment instruments. Since the ratings have a natural order, the ordered probit model was used to analyse the data (see Greene 1993). This type of multiple choice models takes into account the ordinal nature of the dependent variable. The 
TABLE 6 - CHARACTERISTICS OF DISSATISFIED CONSUMERS BY FEATURE AND PAYMENT INSTRUMENT

\begin{tabular}{|c|c|c|c|c|}
\hline & Safety & Cost & Speed & Ease of use \\
\hline Cash & 55-64 years old & $\begin{array}{l}\text { Living in a village } \\
\text { Education: low } \\
\text { EUR } 1800<\text { income } \leq \\
\text { EUR2600 }\end{array}$ & $\leq 34$ years old & $\begin{array}{l}15-24 \text { years old } \\
\text { Education: } \\
\text { higher vocational } \\
\text { Income } \leq \\
\text { EUR } 1800\end{array}$ \\
\hline Debit card & $\begin{array}{l}15-24 \text { years } \\
\text { old } \geq 35 \text { years } \\
\text { old Education: } \\
\text { intermediate } \\
\text { Income } \leq \\
\text { EUR } 1800\end{array}$ & $\begin{array}{l}35-44 \text { years old Living } \\
\text { in a city } \\
\text { Living in a village } \\
\text { Education: low and } \\
\text { intermediate } \\
\text { Income } \leq \text { EUR } 1150 \\
\text { and EUR } 1800< \\
\text { income } \leq \text { EUR } 2600\end{array}$ & $\begin{array}{l}\text { Man } \leq 65 \text { years } \\
\text { old Living in a } \\
\text { major city } \\
\text { Not working }\end{array}$ & $\begin{array}{l}\text { Man Living in a } \\
\text { major city }\end{array}$ \\
\hline E-purse & $\begin{array}{l}\text { Woman } \\
\text { Income } \leq \\
\text { EUR1800 }\end{array}$ & $\begin{array}{l}\text { Education: low and } \\
\text { intermediate } \\
\text { Income } \leq \text { EUR } 1150\end{array}$ & $\begin{array}{l}\text { Education: low } \\
\text { Income } \leq \\
\text { EUR1800 }\end{array}$ & $\begin{array}{l}\text { Income } \leq \\
\text { EUR1800 }\end{array}$ \\
\hline Credit card & $\begin{array}{l}\text { Education: } \\
\text { intermediate } \\
\text { EUR1150< } \\
\text { income } \leq \\
\text { EUR1800 }\end{array}$ & $\begin{array}{l}25-56 \text { years old } \\
\text { Education: }<\text { university } \\
\text { Income } \leq \text { EUR } 1150\end{array}$ & $\begin{array}{l}\text { Living in a } \\
\text { major city } \\
\text { Not working }\end{array}$ & $\begin{array}{l}\text { Education: low } \\
\text { and intermediate } \\
\text { EUR1150< } \\
\text { income } \leq \\
\text { EUR1800 }\end{array}$ \\
\hline
\end{tabular}

following explanatory variables are included in the analysis: age, gender, marital status, educational level, income level and degree of urbanisation of the respondents' residence. In order to increase the readability of this section we have decided to present a summary of the regression results in Table 6, listing the significant characteristics. The interested reader who wants to take a look at the estimation results of the 16 regressions is referred to the appendix.

\subsubsection{General Impression}

The overall picture that emerges is one of more negative appreciation of cash payments among the higher educated, while those with lower to medium levels of education showed above average dissatisfaction with electronic payment instruments. Not surprisingly, the factors having a negative impact on the intensity of use (Table 4) seem to be negatively related to the appreciation.

\subsubsection{Cash}

On closer comparison of individual payment instruments and appreciation aspects, it was found that among the over- $45 \mathrm{~s}$, relatively many respondents 
perceived paying cash as unsafe. The young, higher-educated respondents and medium to high-income earners tend to be slightly more dissatisfied with the user-friendliness and the transaction speed of cash (only the young).

\subsubsection{Debit Card}

Consumers with a low or intermediate educational level perceive paying by debit card as expensive (cardholder fees, surcharges on small payments). On safety, the intermediate educated and people with a (very) low or intermediate income are less satisfied with the debit card (and the e-purse) than those with a high income or a high education. People aged 25-34 years old have most trust in the safety of the debit card. Furthermore, men rated the transaction speed of debit card payments lower and were less satisfied with its ease of use than women. This also holds for people living in one of the major cities. Age did not have a significant impact on the appreciation of the user-friendliness of the debit card. This explains the finding in the previous section that age does not influence the intensity of its use. The debit card is accepted by people of all ages. The significant results for education indicate that on average the respondents in our sample may rate cost of the debit card slightly lower than the Dutch population.

\subsubsection{E-purse}

Consumers with a (very) low income were relatively dissatisfied with the e-purse on all four factors considered. Women tend to think the e-purse is expensive to use and unsafe, and people with a low or intermediate educational level found paying with the e-purse relatively expensive compared to high educated consumers. This indicates that the Dutch population would, on average, rate the costs of the e-purse slightly higher than the people in our sample.

\subsubsection{Credit Card}

Paying by credit card is not very common in the Netherlands. This payment instrument got the lowest rating of all four payment instruments on three out of the four factors considered. Especially consumers who do not earn much or who have (at most) an intermediate educational level think the credit card is unsafe, expensive and are not impressed with its ease of use. The Dutch population may rate the safety, ease of use and cost slightly less favourable, given the difference in educational level of the Dutch population and the sample. City-dwellers and the economically inactive (e.g., students, unemployed, pensioners) disparage the slowness of paying.

\subsection{Barriers and Aversions}

The removal of reluctances (perceived or experienced) by consumers in using cost-efficient payment instruments may help them to pay more efficiently. 
Depending on the nature of their reluctance, it may be overcome through increasing the number of accepting merchants, technological modification of the instrument in question or through public education. Panel members who gave a negative score to an aspect of a payment instrument were asked to explain their reason for doing so.

Table 7 shows the two most-cited aversions by payment instrument and by perception factor. Cash, the second most-cited instrument in terms of unsafety, is regarded as unsafe because of the risk of theft and of money being lost. Other major aversions against cash were the need to search for notes and coins, the time spent waiting for one's change, worries about having enough cash to hand and, in tandem with the last point, the inconvenience of having an overloaded purse. There were not many respondents who indicated the loss of interest revenues on cash holdings as a drawback for using cash.

Consumers with low incomes are less active debit card users than highearning consumers. This difference may be caused by the cost of using these cards, which is perceived to be high compared to the cost of paying cash. Those who regard the debit card as being an expensive payment instrument tend to cite the cost of owning the card and the surcharges levied by some merchants on low-value purchases (transaction costs). Other aversions relating to the debit card are the fear that data on the card or the PIN number may be copied by criminals, the time consumed in making a payment, technical failures and the need to carry your card with you.

TABLE 7 - MAIN AVERSIONS BY PERCEPTION FACTOR AND BY PAYMENT INSTRUMENT $^{\mathrm{a}}$

\begin{tabular}{|c|c|c|c|c|}
\hline & Safety & Cost & Speed & Ease of use \\
\hline \multirow[t]{2}{*}{ Cash } & Theft & Cardholder fee & $\begin{array}{l}\text { Searching for } \\
\text { exact amounts }\end{array}$ & Shortness of cash \\
\hline & Loss & Loss of interest & Receiving change & Overstuffed purse \\
\hline \multirow[t]{2}{*}{ Debit card } & $\begin{array}{l}\text { Copying of } \\
\text { card data }\end{array}$ & Cardholder fee & Processing delay & Need to carry card \\
\hline & $\begin{array}{l}\text { Copying } \\
\text { PIN number }\end{array}$ & $\begin{array}{l}\text { Surcharge low-value } \\
\text { purchases }\end{array}$ & Technical failures & \\
\hline \multirow[t]{2}{*}{ E-purse } & Loss & Cardholder fee & Card reloading & Uncertain balance \\
\hline & Theft & Foregone interest & Processing delay & $\begin{array}{l}\text { Non-universal } \\
\text { acceptance }\end{array}$ \\
\hline \multirow[t]{2}{*}{ Credit card } & $\begin{array}{l}\text { Copying of } \\
\text { card data }\end{array}$ & Cardholder fee & Processing delay & $\begin{array}{l}\text { Non-universal } \\
\text { acceptance }\end{array}$ \\
\hline & Theft & $\begin{array}{l}\text { Surcharge on } \\
\text { purchases }\end{array}$ & $\begin{array}{l}\text { Elapse time } \\
\text { between purchase } \\
\text { and payment }\end{array}$ & $\begin{array}{l}\text { Harder to monitor } \\
\text { expenses }\end{array}$ \\
\hline
\end{tabular}

a Only aversions cited by more than 10 respondents are included. 
The use of the e-purse by consumers has failed to take off. Consumers tend to consider the card as least easy to use, because they are unable to view the balance and because the card is often not accepted. At POS locations where the transaction amounts are usually low, like the baker, greengrocer's shop, kiosk, merchants often do not accept this payment instrument. This latter finding stresses the importance of having both parties (consumers and merchants) on board, when launching a payment instrument. The number of POS payments made by e-purse (but also by debit card) might have been higher if these cards were universally accepted payment instruments. Dissatisfied users and non-users of the e-purse turned out to be fairly unanimous in their criticism. The aversions and barriers with regard to the other perception factors, as experienced by users and non-users of the e-purse, also seem to coincide. Both groups, in addition to the scarceness of acceptance points and an uncertain balance, cite the risk of losing one's e-purse, the need to reload it, transaction times, cardholder fees and the loss of interest on the card's balance (opportunity costs) as disadvantages. A number of these points balance uncertainty, the need to reload, transaction speed - may be remedied by making technological modifications to the card. One of the reasons cited by consumers who usually pay cash (see Table 1) is the way it allows them to monitor their expenses. In order to encourage this group of cash payers to use the e-purse, card issuers could make it easier for consumers to view the balance on the cards. This could be done by publicising existing balanceviewing possibilities, by making balance-reading equipment available at home or in shopping areas or by introducing payment cards with readable balances on the card itself.

Finally, the credit card. This payment instrument is seen by many as unsafe because of the risk that data may be copied and misused by third parties, and also the risk of theft. Moreover, the credit card is regarded as a slow payment instrument because counter payments take time and because of the long elapse time between the date of the purchase and the date it is charged against one's bank account. Finally, it is seen as expensive because of cardholder fees and the surcharges levied on some purchases (high transaction costs). Much-cited aversions concerning the credit card's ease of use are the inability to use the card everywhere and the difficulty of monitoring one's expenses.

\section{CONCLUSIONS}

The Public Perception Survey on POS payment instruments points out clear advantages and disadvantages of the use of the different payment instruments in specific POS situations. These outcomes provide several points of departure for the encouragement of consumers to use the most cost-efficient payment instruments. Stimulating consumers to pay in a more cost-effective 
manner may result in large cost savings on the Dutch retail payment system.

Of the four payment instruments, the debit card received the highest credits in terms of ease of use, safety and transaction speed. Remarkably, cash scored below the debit card on user-friendliness, whereas consumers pay much more often in cash than by debit card. The Survey results show that consumers find paying by the debit card or the e-purse relatively expensive because of transaction costs as opposed to cash, which they regard as inexpensive. Transaction costs are clearly visible for consumers, whereas opportunity costs are easily overlooked. The survey results indicate that transaction costs have a large influence on consumers' payment behaviour. If consumers are made more aware of the social costs of their payment behaviour, they might be persuaded to use cost-efficient means of payment more often than they do now. Imposing tariffs on the use of payment instruments, in a way that would make relatively efficient payment instruments relatively inexpensive to use may prove an important tool in achieving this aim. An interesting finding is that many respondents stated that monitoring expenses is a factor which influences their payment behaviour.

The survey results also stress the importance of non-price features on the payment behaviour of consumers like acceptance, convenience and transaction speed. In daily life the influence of these factors on payment instrument usage can be as large as the impact of perceived cost. Technological modifications to the debit card and, especially, the e-purse will make it more attractive to use these instruments. To begin with, bringing the high transaction speed of e-purse payments to the attention of the public can enhance the epurse's attractiveness as a payment instrument. Secondly, eliminating the risk of e-purse balance insufficiency will also bring real improvement on the current situation. In the third place, making it easier for consumers to access their balance and spending data may induce certain groups of consumers (especially, people who have a low income) to use electronic payment instruments more often. Solutions that suggest themselves are improved public education on card and bank balance viewing possibilities and an expansion of the number of e-purse and bank balance readers (ATMs, POS terminals, shopping centres and home equipment, balance readers on the card itself). Finally, increasing the number of acceptance points for debit cards and especially e-purses will have a positive impact on the number of electronic payments. In order to stimulate the use of electronic payment instruments, attention should also be paid to the question why many merchants do not accept the debit card or the e-purse as a means of payment and why some of them levy a surcharge on card payments. The payment market is a two-sided market. This study clearly shows that payment behaviour in shops does not only depend on the preferences of consumers, but also on the preferences of retailers. More 
theoretical and empirical research on the factors driving the acceptance of payment instruments by retailers may turn out to be a fruitful way to go forward.

\section{APPENDIX RESULTS ORDERED PROBIT ANALYSIS (TABLE 6)}

TABLE A.1 - SAFETY

\begin{tabular}{|c|c|c|c|c|c|c|c|c|}
\hline & \multicolumn{2}{|l|}{ Cash } & \multicolumn{2}{|l|}{ Debit card } & \multicolumn{2}{|l|}{ E-purse } & \multicolumn{2}{|c|}{ Credit card } \\
\hline & Coef. & $\mathrm{Z}$ & Coef. & $\mathrm{z}$ & Coef. & $\mathrm{z}$ & Coef. & $\mathrm{z}$ \\
\hline Male & 0.051 & 1.05 & 0.066 & 1.32 & $0.112^{* *}$ & 2.11 & 0.081 & 1.53 \\
\hline Married & -0.043 & -0.64 & -0.037 & -0.55 & 0.034 & 0.48 & -0.035 & -0.49 \\
\hline Age $15-24$ & -0.062 & -0.34 & -0.124 & -0.66 & -0.115 & -0.58 & -0.291 & -1.45 \\
\hline Age $25-34$ & 0.091 & 0.91 & $0.248^{* *}$ & 2.40 & -0.127 & -1.16 & -0.109 & -1.00 \\
\hline Age $35-44$ & $0.171^{*}$ & 1.83 & 0.092 & 0.97 & 0.077 & 0.75 & 0.000 & 0.00 \\
\hline Age $45-54$ & 0.060 & 0.67 & 0.042 & 0.46 & 0.054 & 0.55 & -0.001 & -0.01 \\
\hline Age 55-64 & $-0.194^{* *}$ & -2.24 & -0.108 & -1.21 & 0.027 & 0.28 & 0.010 & 0.10 \\
\hline City & 0.071 & 0.92 & 0.012 & 0.15 & -0.070 & -0.82 & -0.015 & -0.19 \\
\hline Town & 0.073 & 0.91 & 0.088 & 1.06 & -0.073 & -0.83 & 0.062 & 0.72 \\
\hline Village & 0.096 & 1.20 & 0.090 & 1.10 & -0.103 & -1.17 & 0.005 & 0.06 \\
\hline Countryside & 0.102 & 1.17 & 0.064 & 0.71 & -0.090 & -0.96 & 0.007 & 0.07 \\
\hline d_employed & -0.018 & -0.28 & 0.064 & 0.95 & -0.006 & -0.08 & -0.067 & -0.94 \\
\hline d_study & 0.196 & 1.08 & $0.550^{* *}$ & 2.93 & 0.089 & 0.45 & -0.028 & -0.14 \\
\hline Intermediate voc. ed. & -0.092 & -1.32 & $-0.172^{* *}$ & -2.40 & -0.096 & -1.26 & $-0.218^{*}$ & -2.85 \\
\hline General sec. ed. & -0.079 & -1.03 & -0.088 & -1.12 & -0.043 & -0.51 & -0.082 & -0.99 \\
\hline High voc. ed. & -0.054 & -0.81 & 0.024 & 0.35 & 0.079 & 1.10 & 0.007 & 0.10 \\
\hline University & 0.010 & 0.12 & 0.049 & 0.53 & 0.134 & 1.38 & -0.016 & -0.17 \\
\hline $\begin{array}{l}\text { Net monthly hh } \\
\text { Income }<\text { EUR } 1150\end{array}$ & 0.041 & .41 & $-0.226^{* *}$ & -2.20 & $-0.253^{* *}$ & -2.31 & -0.164 & -1.52 \\
\hline $\begin{array}{l}\text { EUR } 1150 \leq \text { income }< \\
\text { EUR } 1800\end{array}$ & 0.022 & 0.33 & $-0.139^{* *}$ & -2.00 & $-0.166^{* *}$ & -2.26 & $-0.211^{* *}$ & -2.88 \\
\hline $\begin{array}{l}\text { EUR } 1800 \leq \text { income }< \\
\text { EUR } 2600\end{array}$ & -0.083 & -1.40 & $-0.104^{*}$ & -1.72 & -0.041 & -0.64 & -0.015 & -0.23 \\
\hline _cut1 & -2.332 & & -2.651 & & -1.991 & & -2.027 & \\
\hline _cut2 & -1.676 & & -2.192 & & -1.680 & & -1.531 & \\
\hline _cut3 & -1.042 & & -1.690 & & -1.268 & & -1.044 & \\
\hline _cut4 & -0.399 & & -1.051 & & -0.574 & & -0.400 & \\
\hline _cut5 & 0.215 & & -0.321 & & -0.030 & & 0.173 & \\
\hline _cut6 & 1.101 & & 0.956 & & 0.941 & & 1.073 & \\
\hline Log likelihood & -3373.45 & & -2781.100 & & -2878.390 & & -3044.39 & \\
\hline Pseudo $\mathrm{R}^{2}$ & 0.005 & & 0.011 & & 0.007 & & 0.007 & \\
\hline No. Obs. & 2013 & & 2010 & & 1743 & & 1734 & \\
\hline
\end{tabular}

Dependent variable Safety.

Scale $1-7,1=$ very unsafe, $7=$ very safe.

${ }^{*}$ and ${ }^{* *}$ indicate significance at the $90 \%$ and $95 \%$ level of significance, respectively. 
TABLE A.2 - TRANSACTION SPEED

\begin{tabular}{|c|c|c|c|c|c|c|c|c|}
\hline & \multicolumn{2}{|l|}{ Cash } & \multicolumn{2}{|c|}{ Debit card } & \multicolumn{2}{|l|}{ E-purse } & \multicolumn{2}{|c|}{ Credit card } \\
\hline & Coef. & $\mathrm{z}$ & Coef. & $\mathrm{z}$ & Coef. & Z & Coef. & $\mathrm{z}$ \\
\hline Male & 0.041 & 0.82 & $-0.112^{* *}$ & -2.22 & -0.040 & -0.73 & -0.014 & -0.26 \\
\hline Married & 0.110 & 1.62 & -0.031 & -0.45 & -0.005 & -0.06 & -0.023 & -0.32 \\
\hline Age $15-24$ & $-0.314^{*}$ & -1.70 & -0.292 & -1.54 & 0.048 & 0.23 & -0.180 & -0.85 \\
\hline Age $25-34$ & $-0.281^{* *}$ & -2.73 & $-0.269^{* *}$ & -2.58 & 0.051 & 0.45 & -0.070 & -0.63 \\
\hline Age $35-44$ & -0.115 & -1.20 & $-0.229^{* *}$ & -2.37 & 0.034 & 0.32 & -0.019 & -0.18 \\
\hline Age $45-54$ & 0.024 & 0.26 & $-0.271^{* *}$ & -2.92 & -0.042 & -0.42 & -0.077 & -0.78 \\
\hline Age $55-64$ & -0.078 & -0.87 & $-0.194^{* *}$ & -2.14 & 0.122 & 1.25 & 0.058 & 0.61 \\
\hline City & -0.028 & -0.35 & $0.178^{* *}$ & 2.22 & 0.043 & 0.50 & $0.159^{*}$ & 1.90 \\
\hline Town & -0.013 & -0.15 & $0.165^{* *}$ & 1.99 & 0.034 & 0.37 & $0.144^{*}$ & 1.65 \\
\hline Village & -0.121 & -1.47 & 0.124 & 1.51 & 0.039 & 0.44 & $0.236^{* *}$ & 2.69 \\
\hline Countryside & -0.046 & -0.52 & 0.043 & 0.48 & 0.061 & 0.63 & $0.259^{* *}$ & 2.72 \\
\hline d_employed & 0.015 & 0.22 & $0.170^{* *}$ & 2.51 & 0.082 & 1.12 & $0.182^{* *}$ & 2.49 \\
\hline d_study & -0.009 & -0.05 & 0.213 & 1.12 & $0.351^{*}$ & 1.68 & 0.306 & 1.46 \\
\hline Intermediate voc. ed. & 0.055 & 0.76 & -0.084 & -1.16 & $0.139^{*}$ & 1.75 & -0.020 & -0.25 \\
\hline General sec. ed. & -0.011 & -0.14 & -0.066 & -0.83 & 0.070 & 0.81 & -0.013 & -0.15 \\
\hline High voc. ed. & -0.092 & -1.36 & $-0.117^{*}$ & -1.70 & $0.209^{* *}$ & 2.82 & -0.002 & -0.03 \\
\hline University & 0.053 & 0.58 & -0.058 & -0.63 & $0.209^{* *}$ & 2.08 & -0.020 & -0.21 \\
\hline $\begin{array}{l}\text { Net monthly hh } \\
\text { Income }<\text { EUR } 1150\end{array}$ & 0.073 & 0.71 & 0.020 & 0.19 & $-0.277^{* *}$ & -2.47 & -0.018 & -0.16 \\
\hline $\begin{array}{l}\text { EUR } 1150 \leq \text { income }< \\
\text { EUR } 1800\end{array}$ & 0.048 & 0.69 & 0.035 & 0.50 & $-0.203^{* *}$ & -2.65 & -0.012 & -0.17 \\
\hline $\begin{array}{l}\text { EUR } 1800 \leq \text { income }< \\
\text { EUR } 2600\end{array}$ & -0.048 & -0.79 & -0.015 & -0.25 & 0.002 & 0.03 & -0.051 & -0.78 \\
\hline _cut1 & -2.465 & & -3.223 & & -1.976 & & -1.837 & \\
\hline _cut2 & -1.840 & & -2.745 & & -1.846 & & -1.446 & \\
\hline _cut3 & -1.305 & & -2.020 & & -1.491 & & -1.007 & \\
\hline _cut4 & -0.780 & & -1.387 & & -0.817 & & -0.305 & \\
\hline _cut5 & -0.255 & & -0.606 & & -0.243 & & 0.347 & \\
\hline _cut6 & 0.445 & & 0.499 & & 0.739 & & 1.226 & \\
\hline Log likelihood & -3223.32 & & -2714.95 & & -2503.18 & & -2826.78 & \\
\hline Pseudo $\mathrm{R}^{2}$ & 0.006 & & 0.005 & & 0.010 & & 0.004 & \\
\hline No. Obs. & 2011 & & 2007 & & 1696 & 1695 & & \\
\hline
\end{tabular}

Dependent variable Transaction speed.

Scale: $1-7,1=$ very low transaction speed, $7=$ very high transaction speed.

${ }^{*}$ and ${ }^{* *}$ indicate significance at the $90 \%$ respectively $95 \%$ level of significance. 
TABLE A.3 - COST PERCEIVED BY CONSUMERS

\begin{tabular}{|c|c|c|c|c|c|c|c|c|}
\hline & \multicolumn{2}{|l|}{ Cash } & \multicolumn{2}{|c|}{ Debit card } & \multicolumn{2}{|l|}{ E-purse } & \multicolumn{2}{|c|}{ Credit card } \\
\hline & Coef. & $\mathrm{z}$ & Coef. & $\mathrm{z}$ & Coef. & $\mathrm{Z}$ & Coef. & $\mathrm{z}$ \\
\hline Male & -0.071 & -1.28 & -0.033 & -0.67 & 0.033 & 0.61 & 0.004 & 0.08 \\
\hline Married & 0.054 & 0.70 & 0.036 & 0.54 & 0.020 & 0.28 & 0.024 & 0.33 \\
\hline Age $15-24$ & 0.161 & 0.78 & 0.066 & 0.35 & -0.113 & -0.55 & 0.039 & 0.19 \\
\hline Age $25-34$ & 0.131 & 1.14 & 0.167 & 1.64 & 0.085 & 0.77 & $0.495^{* *}$ & 4.50 \\
\hline Age $35-44$ & $0.206^{*}$ & 1.95 & $0.207^{* *}$ & 2.20 & 0.098 & 0.95 & $0.387^{* *}$ & 3.77 \\
\hline Age $45-54$ & -0.018 & -0.18 & 0.147 & 1.63 & 0.021 & 0.21 & $0.323^{* *}$ & 3.30 \\
\hline Age $55-64$ & -0.055 & -0.54 & 0.073 & 0.82 & 0.019 & 0.19 & $0.246^{* *}$ & 2.61 \\
\hline City & 0.048 & 0.53 & $0.246^{* *}$ & 3.13 & 0.045 & 0.52 & $-0.173^{* *}$ & -2.09 \\
\hline Town & 0.027 & 0.29 & 0.116 & 1.42 & -0.017 & -0.19 & $-0.214^{* *}$ & -2.47 \\
\hline Village & 0.127 & 1.38 & $0.217^{* *}$ & 2.68 & 0.088 & 0.99 & -0.057 & -0.66 \\
\hline Countryside & $0.224^{*}$ & 2.24 & $0.289^{* *}$ & 3.26 & 0.135 & 1.40 & -0.083 & -0.88 \\
\hline d_employed & -0.012 & -0.16 & -0.050 & -0.76 & -0.105 & -1.46 & -0.073 & -1.01 \\
\hline d_study & 0.186 & 0.90 & -0.021 & -0.11 & -0.019 & -0.09 & -0.072 & -0.35 \\
\hline Intermediate voc. ed. & -0.127 & -1.60 & $0.121^{*}$ & 1.72 & -0.007 & -0.09 & $0.230^{* *}$ & 2.97 \\
\hline General sec. ed. & $-0.161^{*}$ & -1.84 & -0.012 & -0.16 & -0.067 & -0.79 & $0.234^{* *}$ & 2.74 \\
\hline High voc. ed. & $-0.165^{* *}$ & -2.18 & -0.059 & -0.89 & -0.025 & -0.34 & 0.116 & 1.61 \\
\hline University & -0.145 & -1.41 & $-0.161^{*}$ & -1.78 & $-0.198^{* *}$ & -2.00 & -0.109 & -1.16 \\
\hline $\begin{array}{l}\text { Net monthly hh } \\
\text { Income }<\text { EUR } 1150\end{array}$ & 0.082 & 0.73 & $0.214^{* *}$ & 2.11 & $0.234^{* *}$ & 2.14 & $0.216^{*}$ & 1.99 \\
\hline $\begin{array}{l}\text { EUR } 1150 \leq \text { income }< \\
\text { EUR } 1800\end{array}$ & 0.027 & 0.36 & 0.083 & 1.21 & 0.099 & 1.32 & 0.051 & 0.69 \\
\hline $\begin{array}{l}\text { EUR } 1800 \leq \text { income }< \\
\text { EUR } 2600\end{array}$ & $0.140^{* *}$ & 2.09 & $0.152^{* *}$ & 2.54 & 0.038 & 0.58 & 0.079 & 1.23 \\
\hline _cut1 & 0.362 & & -0.518 & & -0.665 & & -1.367 & \\
\hline _cut2 & 0.941 & & 0.178 & & -0.020 & & -0.817 & \\
\hline _cut3 & 1.223 & & 0.678 & & 0.477 & & -0.259 & \\
\hline _cut4 & 1.849 & & 1.347 & & 1.158 & & 0.416 & \\
\hline _cut5 & 2.093 & & 1.927 & & 1.670 & & 0.969 & \\
\hline _cut6 & 2.465 & & 2.471 & & 2.094 & & 1.573 & \\
\hline Log likelihood & -2387.55 & & -3434.89 & & -2906.50 & & -3068.56 & \\
\hline Pseudo $\mathrm{R}^{2}$ & 0.011 & & 0.008 & & 0.005 & & 0.013 & \\
\hline No. Obs. & 1981 & & 1980 & & 1689 & & 1682 & \\
\hline
\end{tabular}

Dependent variable Cost.

Scale $1-7,1=$ very cheap, $7=$ very expensive.

$*^{*}$ and ${ }^{* *}$ indicate significance at the $90 \%$ respectively $95 \%$ level of significance. 
TABLE A.4 - EASE OF USE

\begin{tabular}{|c|c|c|c|c|c|c|c|c|}
\hline & \multicolumn{2}{|l|}{ Cash } & \multicolumn{2}{|l|}{ Debit card } & \multicolumn{2}{|l|}{ E-purse } & \multicolumn{2}{|c|}{ Credit card } \\
\hline & Coef. & z & Coef. & $\mathrm{z}$ & Coef. & $\mathrm{z}$ & Coef. & z \\
\hline Male & -0.029 & -0.57 & $-0.247^{* *}$ & -4.60 & -0.056 & -1.01 & 0.014 & 0.25 \\
\hline Married & 0.074 & 1.05 & -0.009 & -0.13 & -0.073 & -0.99 & 0.052 & 0.71 \\
\hline Age $15-24$ & -0.105 & -0.56 & -0.023 & -0.12 & 0.030 & 0.14 & -0.314 & -1.47 \\
\hline Age $25-34$ & -0.030 & -0.28 & 0.025 & 0.23 & -0.088 & -0.79 & 0.065 & 0.58 \\
\hline Age 35-44 & 0.057 & 0.58 & 0.085 & 0.83 & -0.056 & -0.54 & 0.068 & 0.64 \\
\hline Age $45-54$ & $0.198^{* *}$ & 2.09 & 0.001 & 0.01 & 0.040 & 0.40 & 0.075 & 0.74 \\
\hline Age $55-64$ & -0.026 & -0.29 & -0.036 & -0.38 & 0.097 & 1.00 & $0.186^{*}$ & 1.91 \\
\hline City & -0.021 & -0.26 & $0.140^{*}$ & 1.66 & 0.025 & 0.29 & 0.077 & 0.89 \\
\hline Town & 0.030 & 0.36 & $0.188^{* *}$ & 2.13 & 0.090 & 0.99 & 0.038 & 0.42 \\
\hline Village & -0.120 & -1.43 & 0.013 & 0.16 & 0.008 & 0.09 & 0.089 & 1.00 \\
\hline Countryside & $-0.171^{*}$ & -1.87 & -0.024 & -0.25 & 0.093 & 0.95 & -0.014 & -0.14 \\
\hline d_employed & 0.061 & 0.88 & $0.140^{*}$ & 1.95 & -0.019 & -0.26 & 0.115 & 1.54 \\
\hline d_study & -0.071 & -0.37 & -0.024 & -0.12 & 0.114 & 0.55 & 0.307 & 1.43 \\
\hline Intermediate voc. ed. & -0.014 & -0.19 & -0.120 & -1.58 & 0.001 & 0.02 & -0.049 & -0.61 \\
\hline General sec. ed. & -0.027 & -0.33 & 0.017 & 0.20 & -0.049 & -0.57 & 0.068 & 0.77 \\
\hline High voc. ed. & $-0.213^{* *}$ & -3.09 & -0.050 & -0.69 & -0.012 & -0.17 & $0.148^{* *}$ & 2.01 \\
\hline University & -0.129 & -1.38 & -0.021 & -0.22 & -0.044 & -0.44 & 0.050 & 0.51 \\
\hline $\begin{array}{l}\text { Net monthly hh } \\
\text { Income < EUR } 1150\end{array}$ & $0.306^{* *}$ & 2.85 & -0.062 & -0.56 & $-0.343^{* *}$ & -3.10 & -0.176 & -1.57 \\
\hline $\begin{array}{l}\text { EUR } 1150 \leq \text { income }< \\
\text { EUR } 1800\end{array}$ & $0.152^{* *}$ & 2.15 & -0.099 & -1.34 & $-0.165^{* *}$ & -2.18 & $-0.177^{* *}$ & -2.32 \\
\hline $\begin{array}{l}\text { EUR } 1800 \leq \text { income }< \\
\text { EUR } 2600\end{array}$ & -0.030 & -0.49 & -0.069 & -1.07 & -0.064 & -0.98 & -0.100 & -1.50 \\
\hline _cut1 & -2.382 & & -2.613 & & -1.893 & & -1.704 & \\
\hline _cut2 & -1.864 & & -2.465 & & -1.614 & & -1.431 & \\
\hline _cut3 & -1.326 & & -2.241 & & -1.296 & & -1.149 & \\
\hline _cut4 & -0.812 & & -1.724 & & -0.792 & & -0.511 & \\
\hline _cut5 & -0.336 & & -1.068 & & -0.313 & & 0.042 & \\
\hline _cut6 & 0.292 & & -0.058 & & 0.385 & & 0.730 & \\
\hline Log likelihood & -3055.08 & & -2299.70 & & -2848.72 & & -2715.12 & \\
\hline Pseudo $\mathrm{R}^{2}$ & 0.009 & & 0.011 & & 0.004 & & 0.008 & \\
\hline No. Obs. & 2008 & & 2011 & & 1698 & & 1669 & \\
\hline
\end{tabular}

Dependent variable Ease of use.

Scale $1-7,1=$ very hard to use, $7=$ very easy to use.

$*$ and ${ }^{* *}$ indicate significance at the $90 \%$ and $95 \%$ level of significance, respectively. 


\section{REFERENCES}

Baumol, W.J. (1952), 'The Transaction Demand for cash: An Inventory Theoretic Approach', Quarterly Journal of Economics, vol. 66, pp. 545-556.

Boeschoten, W.C. (1992), 'Currency use and Payment Patterns, PhD-thesis', Universiteit van Amsterdam.

Boeschoten, W.C. (1995), 'Kasmanagement en betaalgedrag van gezinnen in 2004', DNB Kwartaalbericht Juni 1995, pp. 19-34.

Boeschoten, W.C. (1998), 'Cash Management, Payment Patterns and the Demand for Money', De Economist vol. 146(1), pp. 117-142.

Boeschoten, W.C. and M.M.G. Fase (1989), 'The Way we Pay with Money', Journal of Business and Economic Statistics, vol. 7(3), pp. 319-326.

Bolt, W. (2006), 'Retail payments in the Netherlands: Facts and theory', De Economist 154 (3), pp. 345-372.

Bolt, W. and A.F. Tieman (2004), 'A Note on Social Welfare and Cost Recovery in Two/Sided Markets', DNB Working paper 24.

Bolt, W., D. Humphrey and R.A. Uittenbogaard (2005), 'The Effect of Transaction Pricing on the Adoption of Electronic Payments: A Cross-Country Comparison', DNB Working paper no 71/Dec 2005.

Borzekowski, R. and E.K. Kiser (2006), 'The Choice at the Checkout: Quantifying Demand Across Payment Instruments', Finance and Economics Discussion Series 2006-17. Washington: Board of Governors of the Federal Reserve System.

Borzekowski, R., E.K. Kiser and S. Ahmed (2006), 'Consumers' Use of Debit Cards: Patterns, Preferences, and Price Response', Finance and Economics Discussion Series 2006-16. Washington: Board of Governors of the Federal Reserve System.

Brits, J.H. and C.C.A. Winder (2005), 'Payments are no free lunch', DNB Occasional Studies, vol. 3/no. 2, De Nederlandsche Bank NV, Amsterdam.

Buiter, W.H. and C.A. Armstrong (1978), 'A Didactic Note on the Transactions Demand for Money and Behavior Towards Risk: Note', Journal of Money, Credit and Banking 10(4), pp. 529-538.

Dotsey, M. (1988), 'The Demand for Currency in the United States', Journal of Money, Credit and Banking, vol. 20(1), pp. 22-40.

DNB (2006), 'Towards a cashless society?', DNB Quarterly Bulletin March 2006.

Duca, J.V. and W.C. Whitesell (1995), 'Credit cards and Money demand: a Cross-sectional Study', Journal of Money, Credit and Banking, vol. 27(2), pp. 604-623.

Fase, M.M.G. and M. van Nieuwkerk (1977), 'The Demand for Bank Notes in four Countries', Quarterly Statistics I, pp. 84-93.

Fase, M.M.G. and W.C. Boeschoten (1985), 'The distribution of payments and the use of bank notes', DNB Quarterly Bulletin, December, pp. 43-53.

GfK/Interpay, (2004) 'Monitor Consumptieve Toonbankbetalingen in Nederland'.

Greene, W.H. (1993), 'Econometric Analysis', 2nd edn, MacMillan Publishing Company, New York.

Hoofdbedrijfsschap Detailhandel (2002), 'Afrekenen in winkels 2002', Den Haag.

Kohli, V. (1988), 'A note on Banknote Characteristics and the Demand for Currency by Denomination', Journal of Banking and Finance, vol. 12(3), pp. 389-399. 
Loix, E., R. Pepermans and L. van Hove (2005), 'Who's afraid of the cashless society', Belgian Survey Evidence, Working Paper.

Van Hove, L. (2000), 'Zijn betaalmiddelen publieke goederen? Over overheidsinterventie en tarifering (Are payment services public goods?)', Revue de la Banque/Bank-en Financiewezen, vol. 2000(1), pp. 15-23.

Van Hove, L., E. Loix and R. Pepermans (2005), 'De Belgische consumenten over elektronisch betalen: resultaten van een opinieonderzoek', Financieel Forum/Bank en Financiewezen, vol. 2005(1), pp. 16-28.

Humphrey, D.B. and A.N. Berger (1990), 'Market Failure and Resource use: Economic Incentives to use different payment Instruments', in D.B. Humphrey (eds.), The U.S. Payment System: Efficiency, Risk and the Role of the federal Reserve, pp. 45-86, Boston, MA: Kluwer Academic Publishers.

Humphrey, D.B., L.B. Pulley and J.M. Vesala (1996), 'Cash, Paper and Electronic Payments: A Cross-Country Analysis', Journal of Money, Credit and Banking, part II (November 1996), pp. 914-939.

Humphrey, D.B., M. Kim and B. Vale (2001), 'Realizing the gains from electronic payments: costs, pricing and payment choice', Journal of Money, Credit and Banking, vol. 33, pp. 216-234.

Hyytinen, A. and T. Takalo (2004), 'Multihoming in the market for payment media: evidence from young Finnish consumers', Discussion paper 25/2004, Bank of Finland.

Klee, E. (2004), 'Retail Payments 1995-2001: Findings from aggregate data and the Survey of Consumer Finances', working paper.

Mishkin, F.S. (2000), 'The Economics of Money, Banking and Financial Markets', 6th edn, Addison Wesley Longman.

Mot, E.S., J.S. Cramer and E.M. van der Gulik (1989), 'De keuze van een betaalmiddel', SEO rapport nr. 228, Stichting voor Economisch Onderzoek der Universiteit van Amsterdam, Amsterdam.

Tobin, J. (1956), 'The Interest-Elasticity of Transactions Demand for Money', Review of Economics and Statistics, vol. 38, pp. 241-247.

Santomero, A. and J. Seater (1996), 'Alternative Monies and the Demand for Media of Exchange', Journal of Money, Credit and Banking, vol. 28, pp. 942-960.

Schuh, S. and J. Stavins (2006), 'To Check or Not to Check: Why Are (Some) Consumers (Finally) Writing Fewer Checks?', working paper, Federal Reserve bank of Boston and the Board of governors of the Federal Reserve System.

Shy, O, and Tarkka (2002), 'The Market for Electronic Cash Cards', Journal of Money, Credit and Banking, vol. 34(2), pp. 299-314.

Stavins, J. (2001), 'Effect of Consumer Characteristics on the Use of Payment Instruments', New England Economic Review, vol. 3, pp. 21-31.

Zinman, J. (2005), 'Why Use Debit instead of Credit? Consumer Choice in a Trillion Dollar market', Mimeo, Federal Reserve Bank of New York. 